\title{
The Populist phenomena and the reasons for their success in Hungary ${ }^{1}$
}

\author{
VIKTOR GLIED
}

\section{Sciendo}

Politics in Central Europe (ISSN: 1801-3422)

Vol. 16, No. 15

DOI: $10.2478 /$ pce-2020-0002

\begin{abstract}
After the parliamentary elections in 2014, the weakened legitimacy of the Hungarian government could be re-established through activism in migration issues. Fidesz-KDNP that won elections twice already highlighted migration as the main theme of governance from 2014 to 2018, suppressing every other topic on the political agenda. The position that was established for purposes of the Hungarian domestic situation and politics initially faced intense rejections all over Europe, but then garnered some supporters as well, mostly in post-socialist Central and Eastern Europe, and to a smaller extent among the right-wing and populist parties of Western Europe. The anti-refugee and populist approach caused significant success in the communication field to the subscribing parties and governments, and also legitimised Hungarian government's efforts that could mean it met the majority of the Hungarian society's expectations. The most essential question is that how can political science reshape its terms and thoughts on populism to understand this phenomenon better, moreover what are the reasons of populism and why is the populist propaganda such successful in Hungary and Eastern Europe.
\end{abstract}

Keywords: Hungary, populism, history, migration, manipulation

\section{Introduction}

The long-lasting economic recession following the global financial crisis of 2008; the 'revival' of Russia's claims to being a global power; the so-called "soft

1 This research project was supported by the European Union. EFOP-3.6.3-VEKOP-16-2017-00007 - Young researchers from talented students - Fostering scientific careers in higher education. 
power" applied to enforce economic and political intervention; the EU's answer to the Greek crisis; Brexit and the migration crisis after 2015 have all shaken up Central-European party systems, as well as the political/ideological directions they take. Europe can hardly recover from the shock of a crisis before it is hit by the next one and meanwhile, it continues to gradually lose its global significance, as well as its economic and political influence. The crisis phenomena piling up and increasing each other's impact has led to a vicious circle of political responses failing to solve problems and identify the root causes thereof, promising short-term, cursory, although efficient, treatment. Instead of providing valid explanations for the crises, they curtail, distort reality and show an assumed or false image thereof. Because of the aforementioned complex factors, a general right-wing turn, the shift of the mid-left and mid-right political sides, as well as the rise of an anti-elitist, anti-establishment and populist paradigm can be observed. The governing parties of Central and Eastern Europe (also including Austria and the Czech Republic), as well as Southeast Europe and/or the parties which seized power as a consequence of all this, have all successfully jumped on the Eurosceptic and anti-immigration bandwagon shouting populist slogans. At the same time, radical parties have gained ground in almost every European country, with the Donald Trump phenomenon also bringing along an entirely new era in the US, as Evo Morales and others in Latin-America (Deák 2019: 56).

Almost three decades after the transition to the market economy and the democratic multi-party system, the Hungarian public dominantly feels indifference, disillusionment and the necessity of heated and radical reforms. With the catastrophic defeat of left-leaning liberal parties in 2010, the governing Fidesz-KDNP (Alliance of the Young Democrats and the Christian Democratic People's Party) have triumphed at parliamentary elections three times. This period can be divided into two major parts: (1) The period from the $2009 \mathrm{Eu}-$ ropean Parliamentary election to late 2014, and (2) the period dominated by the migration crisis and a new public discourse from 2015 to 2018. This paper examines the reasons of populism and the reasons for the success of populist propaganda in Hungary and Eastern Europe.

\section{The 'reinterpretation' of populism}

Populism has become one of the most common and trending terms of political science in the 21st Century. It is starting to become the new 'climate change' in the sense that it can be applied to everything; it can be blamed for any unfavourable occurrence and can be used to explain anything. Tax cuts? Attending sport events? A meal eaten in public? A First Lady in fashionable garments? Openly inciting hate? Are these all for nothing but pure populism and is this necessarily something evil in all cases? Many complicated questions make it clear why the definition of populism is not easy to give. Of course, we know 
and recognise the phenomenon, talk about it and describe it in detail but the concepts are so complex, diverse, abstract and take elements from all aspects of social sciences. Although it has some specific characteristics and identifiable common features, its nature is ever-changing (Van Reybrouck 2010), both in time and space. Permissively, populism can be called an ideology-free ideology, with the single component of representing the will of the people (considered to be homogeneous), in both the positive and negative sense. Thus, it can be left-wing or right-wing as well, since both sides can claim to be "standing by the people, against the (former) elites". Gábor Győri agrees with this in his expressing the following definition (after examining the phenomenon from multiple aspects): "the concept of populism covers tools and means based on popular fears [...] and suggests a true representation of the people [...] emphatically against the political elit." (Győri 2008: 16). With a slightly sceptical approach, it can be called a paradigm generated, supported and reinforced by populist politics, overwhelming the political agenda and thus also the discourse but it can also be considered a creatively Machiavellian set of objectives which seem like a political programme but only serve mechanisms of power technique (Kovács 2011: 260). In a simplified manner, it can be called a political strategy narrowed down to a consequential series of tactical steps which degrade the interactions of the political community to a game of political communication and has no other purpose than creating a parallel reality as the alternative to mainstream politics which gives a voice to disillusioned, lost, offended, angry, frustrated and vengeful people (Müller 2018: 9). And frustrated, cynical people who have lost faith are open to blaming others for their fate and for how things are going. This is supported by a statement by Pope Francis from 2017 in which he blends populism with the xenophobic sentiment increasing due to the migrant crisis after 2015 and the acts of terrorism committed all over Europe: "When I was told of populism here, I didn't understand much of it, I was lost, until I realised that it has different meanings depending on the location. Obviously, crisis leads to fear and panic." It is very likely that with the political reality of the 21st century, we have to say that populism encompasses all these but with a sharp statement, it is nothing else but a bunch of reactions to actual or putative events, articulated in a simple and instinctive way, without any actual substance, aiming to polarise the public and gain political advantage (Canovan 1999).

But why is this whole issue so complex despite just getting the clear answers? Because we do not yet know all the impacts and characteristics of this phenomenon in detail. Populist politics and the reactions thereto keep changing constantly. Our current knowledge is only enough to understand, rather than describe it. In addition to being an effective means of obtaining and keeping power, as well as

2 Interview with Pope Francis in the Spanish daily El País. http://www.magyarkurir.hu/hirek/ferenc-papa-interjuja-az-el-pais-spanyol-napilapnak (25 January 2017). 
a manifestation of the desire for popularity, populism may also designate a legitimacy principle in which self-justification overpowers any other pragmatic and rational action and argument, or merely provide a sympathetic alternative for a lack thereof. All this, coupled with an exclusive identity policy (the establishment and use of the groups of Us and Them) provide a complex approach to the world in which populists are the people and the nation and everyone else with different opinions is simply not part of the group, part of the corrupt political elite or (more sharply) an alien and a traitor (Bayer 2008: 42; Hamerli 2019). In this sense, Pierre-André Taguieff (1995) distinguishes between "identity-national" populism and protest populism. In the former case, the people's national image "under threat by aliens" is emphasised, while in the latter case, critical and radical anti-elitist sentiment appears and sometimes these are mixed.

In case one of the characteristics of populism is exiting the framework of political correctness and using rhetoric previously only used by far-right and far-left regimes in politics, social science cannot escape from facing the challenge honestly. If we responsibly try to think outside the box of the "on the one hand... on the other hand" approach (aiming to paint a scientific picture), we are faced with the definition given by David Van Reybrouck: "populism is a style of making politics on the one hand, when someone is not afraid of catching the attention of masses with simplifications, meaningless buzzwords and programme objectives narrowed down to single sentences" (Van Reybrouck 2010: 13). Based on the above, populism is a rhetoric means of reaching the widest possible audience, with the simplest possible tools and communication formats. Contrary to the above approaches, Ernesto Laclau has a different (and probably obsolete) perspective to grasp the concept. In his opinion, "populism is not a type of movement, [...] but a type of political logic" (Laclau 2011: 138). Conflicting my view, he does not consider populism a rhetoric method but practically a kind of logic that is an unavoidable part of any social change. In my opinion, in the present, these two processes operate in a symbiotic way as two phenomena inseparable from each other. Gustave Le Bon (2002) - a source considered a classic - at the end of the 19th Century, obviously did not use the term but in his work discussing the behaviour of the masses, he emphasised that with the appropriate rhetoric, a statesman could depict the most hated measures as acceptable. This argument also supports the view that this term mostly applies to political rhetoric, which was used later, with regard to mass propaganda in the 20th Century. These are supported by the fact that populist leaders are typically charismatic leaders; personalities with identifiable traits. They apply novelty, innovative political means and campaign techniques, pursue a divisive political strategy, transform and tame the institutions, change the political system, step over conventions and also encourage their supporters to do so. Populist politicians are proactive and actively acting participants of the events. Their aim in doing so is merely to show the direction and to stay one step ahead of their foes. In many cases, they 
generate the need to make decisions without a single correct answer, merely in order to show the discrepancy between ethical, or apparently national- and loyalty-related dilemmas and material financial decisions affecting everyone. The populist politician shall be the single bearer of the truth: "One Ring to rule them all, One Ring to find them, One Ring to bring them all and in the darkness bind them". In order to prove his own anti-elitism, he takes efforts to be in direct contact with the people. He blends with the crowd, inaugurates developments, shows human weaknesses, worries and keeps being funny (Mair 2002: 88-90).

Political science in the 21st Century faces numerous unanswered questions which have an impact on people every single day, no matter where they live. Do politics and politicians even exist without elements of populism? Successful politicians probably do not. It is assumed that someone becomes a politician because they want to fight for the common good or because they have ambition for power, or possibly they are discontent, a little exhibitionist and want to enjoy personal fulfilment through taking public political roles but a common trait each politician has is in thinking that they satisfy the will of the people. While political science relates, compares, deliberates and searches for patterns, trying to explain events of the past as reflected in the present or the future, populist politicians proclaim and claim that they speak the truth "based on the facts". Populism cannot allow dilemmas or dissent; there are no grey areas or hesitation. Populist politicians usually see the world in black and white.

In practice, this means that they cover actual issues with a 'larger' challenge, ranking higher in the hierarchy of interests. This is typically an international conflict, the action of another country, people or group, their 'attack' or malice, or the appearance of a group different from the culture or religion of the specific community; the alien. We know and understand where this kind of scapegoating and scaremongering against newly created enemies has led throughout history, although these had also clearly been important factors in strengthening the identities and potential actions of the people, a community or a group, as well as in mobilising them. We also know what happened when radical, nationalist/ chauvinist/racist political forces obtained power and used the entire state machinery to reach their goals. Still, from time to time, we step into the same river and watch as a 'light-minded populist talk' leads to hate speech and incitement. Prejudice, stigmatisation and xenophobia have accompanied our history and are still present in an increasing number of places. Who is it up to decide who is an alien and what makes them one? A different skin colour, religion, name or sexual orientation? Pronouncing someone an alien is an internal process which separates certain communities, groups, or even nations and civilisations based on cultural, religious and linguistic differences, in an inward-looking manner. While tolerance against aliens exists, the peaceful co-existence between 'us' and 'them' works but different types of crises - as history clearly shows - can bring certain forms of xenophobia to the surface, determined by the cultural 
traditions and historical experiences of society and these leave a mark on the political thinking of the community. If the government pursues an efficient integration (and assimilation) policy, then possible differences can blur and then resurface and be questioned again from time to time, but a serious social crisis may be averted. In places where those in power intend to keep their position and maintain a grip on power by inciting xenophobia, along with the anger of certain social groups against each other, this can lead to serious distortions and even violence, in extreme cases (Nyíri 2003). When examining the relationship of economic crisis and scapegoating, the significance of psychological factors is highlighted because a significant proportion of a disillusioned society may be willing to receive the over-simplified messages. This encourages researchers to interpret the results of populism and xenophobia in relation to political rhetoric and psychological factors. Populism "can impact anyone if they are afraid, angry or discontent" (Van Reybrouck 2010: 16).

In the populist framework, emotional approaches and instinctive reactions override equity and reason in all cases. Their objective is not to uncover the truth and elements of reality but to transform, hide, bend and also change the rhetorical and ideological arena, thus creating a special context for political discourse, dominated by a single logical set of power objectives. First of all, it takes effort to dominate the political agenda and on the other hand, by using fake news, fake events, half-truth and lies, fictional stories and conspiracy theories, it aligns artificially created reality with factors triggering political action (Harari 2018: 205). This is still just self-justification, thus providing an alternative world-view which provides a simple, flexibly changeable point of alignment for a normless, indifferent society choking on unnecessary information in which human values and people themselves are merely reference points. In this system, causal relationships form no actual logical chain; they are degraded to become tools of political communication. But what is reality? Nowadays, anything can be questionable. Isn't this so?

We can ask the question: if we know so much about populism, how can it still be so successful as a political view? In order to answer this, we only need to understand history. In the period following the World War II, the key challenge to political science (in its own interpretation) was providing a system for politicians that is democratic, protects the rule of law and can also avoid the creation of totalitarian dictatorships. The West found consensus in pronouncing liberal democracy as the only possible way of avoiding crises and wars, at the same time also ensuring liberties and the constant growth of the economy. The student protests in 1968 which targeted a lack of facing the past and solving social injustice, as well as the post-materialist movements from the 1970s and 1980 s, did not question the fundamentals of the viability of liberal democracy; they only wanted to adjust, rather than change global processes. The rapid technological changes in the 2000s, the global financial and economic crisis from 2008, the Arab Spring and the migration crisis after 2015 fundamentally 
changed the existing world, creating an opportunity for populist forces to rise. Liberal democracy leaves many issues for people face-open because it cannot answer them without losing its credibility. Examples include disputes over data privacy and personal rights vs. security and controlling society; the lack of countering financial anomalies; or religious freedom vs. wearing traditional religious and political symbols. As democracy has started to weaken in the 21st Century, people have become mistrustful towards traditional political institutions, while populism can provide (albeit skin-deep) solutions to millions (Antal 2017). We have to understand that populism is not an antidemocratic phenomenon because it typically grows in the soil of democratic systems as a reaction to existing problems. It seemingly respects the democratic rules and also keeps the related institutions but at the same time, it creates a structure in which democracy and the rule of law are only a façade in front of pure political rationale.

\section{Background of the rise of populism in Hungary}

In the late 20th century, democracy has also prevailed over the oppressive dictatorships (communist systems in this case) in Eastern Europe. The opportunity for democratic consolidation was open during the political and economic transition but the permanent failure of liberal democracy, surrounded by empty promises, lead to the repeated and radical reappearance of populism. During a brief century, the society of Hungary has undergone eight revolutions and regime changes. Each of these have also involved an obligatory change of ideology, meaning that the reigning government tried to reshape society according to its own ideals. This could not be successful due to ever newer regime and system changes meaning deeply rooted social and political conflicts could not be resolved. Traumas of 20th Century Hungarian history hit society hard. All these were further increased by traditional grievance politics which is rooted in the 19th Century. It is known for demonising political opponents and causing political paranoia which has hindered (and still hinders today) agreeing on national minimums in certain issues (1).

The radical change of 1988-1990 in the form of the regime change brought about major shifts in the life of Hungarian society, from a Communist system rapidly into fully-fledged capitalism and a market economy. From one day to the next, one and a half million people experienced the end of 'full employment' and lost their jobs, while income inequality increased, suddenly the value of the income of lower and middle classes shrank. Uncertainty and fear for the future, as well as extreme poverty resurfaced, thus increasing the experience of 'being a loser' in vast groups of society. Meanwhile, the government could only encourage people by giving them messages like, "we only have to suffer a little more" and "we will soon catch up with the Austrian standard of living". Without long-term strategies, the governing forces rapidly changed courses multiple times, 
kept spending to win over votes and then applied austerity measures to resolve budget deficit. As a result, the former leader of the class, Hungary, began to lose its competitive advantage in the 1990s and gradually started to fall behind in the areas of economic development as well as managing social injustices. The anti-communist rhetoric of the transition to democracy was later reframed into the rural-traditional vs. urban-cosmopolitan dispute, with anti-Semitic, anti-Gypsy formats and ways of conspiracy theories, as much in politics as in public discourse. The tone gradually radicalised, exceeding the threshold and tolerance of the people, giving way to the forgotten extreme ideologies. Nostalgia for the Socialist system and Kadarism ${ }^{3}$, however, is still prevalent in a significant part of Hungarian society; the terms "good leader", "one of the people" and 'pandering non-verbal agreement' are known to every Hungarian (2) (Schmidt 2018: 75). As a consequence of uneven territorial opportunities, the development of urban and rural areas parted ways. The paternalistic attitude prevailed and the customs of looking for shortcuts when looking for administrative solutions became a typical means of problem-solving. A significant share of Hungarian society is still committed to believing that public procurements are decided based on the internal deals of the elite and corruption is par for the course in politics.

It is safe to say, therefore, that softer elements of the social climate favourable to extremists were already present in society after the regime change. Indeed, these changes can clearly facilitate the increasing popularity of parties communicating strong messages in which they urge radical solutions. Anti-Semitism, invoking the rhetoric and symbols of the interbellum period, re-surfaced in the country, while xenophobia and racism (antiziganism, anti-Roma sentiment) also gained ground. The sense of threat and existential vulnerability caused by "strangers" has mainly been prominent among the groups adversely affected by the regime change and anti-Roma attitudes are also more typical for them (Csepeli - Örkény 1996).

After the transition to democracy, the liberals who had used radical anti-Communist rhetoric beforehand, established their own political movement in 1991 under the name "Democratic Charta". Their main objective was to highlight that the nationalist/conservative cabinet from 1990 drifted toward restoring the authoritarian right-wing populist politics of the interbellum period. This rhetoric kept changing between moderate and radical forms but they claimed the danger of the returning fascism (Gyurácz 2017). Hungarian history after the regime change has seen this brand of fascism returning many times because the left applied this claim to mobilise its voters against a far-right danger on numerous occasions. The atomised and mostly apolitical Hungarian society - with a common fate in the Pannonian Basin - failed to agree on a joint perspective and approach to its past (especially its darker periods) and therefore it cannot

3 The Communist system in Hungary from 1957 to 1989 lead by general secretary János Kádár. 
be expected to interpret the anomalies arising in explaining the servile support provided to extreme (fascist and communist) regimes. Who, how and to what extent are responsible for the tempestuous 20th Century history of Hungary? The prevailing and too deeply-rooted sentiments and attitudes identify historical traumas such as defeat in both world wars, the catastrophe of the Hungarian Second Army, the Holocaust, failed revolutions or the atmosphere of the 1950s dominated by Communist terror as neutral events of the past, instead of historical experience to learn from. Since we are unable and not really willing to comprehend it, we rather try to reframe or reinterpret it, if our interests so dictate, and if not, we tend to put these behind us and forget about them. Anyway, the lack of historical clarity and the over-politicised nature of history has created parallel perspectives, primarily regarding ancient Hungarian history and relations with other peoples and nations, as well as our origins and past religion. Populist politics tend to put forward some of the key issues from time to time, which often lead to emotions running high. Such decoys include issues such as:

- who is Hungarian and what is Hungarian;

- who is responsible for negative tendencies;

- doublespeak and masked racism/anti-Semitism (with "you know who" being responsible);

- groups or persons too vulnerable or unable to strike back;

- the 'playing off certain social groups against other groups' card.

When we discuss political culture in Hungary, or the lack of it, which is intertwined with public thinking, the ideas of political scientist István Bibó (2002) cannot be avoided. According to him, the failed freedom fights, the cul-de-sac of Hungarian history always seeking the favours of a major power, led to a distorted national character which created its approach to the world as a mosaic of fiction, presumptions, claims and desires and which does not want to accept reality. Blaming others, the traditional grievance politics of Hungarian history, endless complaints, passing on responsibility, turning a blind eye and being extremely cynical are all parts of the Hungarian way of life and thus these patterns also appear in populist behaviour (3). This leads to some extremely radical expressions, such as the outburst of writer Ákos Kertész in 2011, saying the following about Hungarians: "Magyars are genetically underlings. [...] Magyars never feel even a hint of remorse for the most serious historical crimes, they blame others for everything, point their fingers at other, while they also happily wallow in the swamp of dictatorship, oink and eat up pigwash [...]. They can't and won't learn or work, only envy and murder anyone who gets any success in work, learning or innovation". 4

4 Tamás Pilhál: Magyargyalázás egy Kossuth-díjastól. [Kossuth Prize winner shames Hungarians] Available at: https://mno.hu/migr_1834/magyargyalazas-egy-kossuthdijastol-878305. 12 September 2011 (06 February 2018). 
Partially in response to this liberal flagellation, Viktor Orbán announced "illiberal democracy" in 2014, which claims to respect the democratic framework: there are opposition parties and elections ${ }^{5}$ are held but it rejects the political correctness, habits and rhetoric of liberalism. It depicts itself as 'straight talk' and promises a new world order which brings about major transformations in the early 21st Century powers of finance, world economy, world trade, global powers and militaries. This new order breaks up with the unquestionable direction of intertwining in globalism, becoming universal and commercialistic, which were prevalent after the regime change, and establishes a new system of sovereign national communities. In this structure, Hungary becomes a civic, conservative and Christian state in Central Europe that is competitive, innovative and able to protect its citizens, as well as old European values (Bretter 2016). Liberal democracy does not serve national interests, it generally defies the idea of a national interest even existing, it does not believe that Hungarians around the world are parts of the Hungarian nation and community and it fails to protect families. In his speech, Viktor Orbán clearly explained what the illiberal Hungarian state would look like: “It doesn't deny the fundamental values of liberalism, such as liberty [...], but it doesn't make this ideology a central element of organising the state; it includes a different, specific and national approach." ${ }^{\prime}$

\section{Between East and West... but in or out?}

Nowadays, the society of Hungary is practically ethnically homogeneous, the assimilation of minorities is considered very advanced. The only social integration issue is related to the Roma minority and is referred to in political debates in welfare and public safety related contexts. However, the majority of the Hungarian population is also strongly divided culturally and politically. Certain social groups (especially within the intelligentsia) are sensitive to specific issues of national identity. These groups are highly concerned about ancient Hungarian history, the fates of peoples joining the Magyars (the Hungarian people) and the assimilated populations. A prominent theory professed by certain groups of Hungarian society since the 19th Century (with variable intensity), especially lately from the 1990s, states that Hungarian people are related to oriental populations and it has increased in popularity and acceptance. This "old and new" Hungarian history interprets ancient Hungary and the origins of the Magyars in a radically different way than scientific history and it has become very popular among self-recognised right-wing and nationalistic groups. This alternative interpretation of history blends oriental origins with close ties to

5 Further information about the electoral reform and the new electoral system: Vörös 2016.

6 Full text of Viktor Orbán's speech. Available at: https://mno.hu/belfold/orban-viktor-teljes-beszede-1239645. 29/07/2014 (15 April 2015). 
Turks, the theory of Hun-Hungarian continuity, stating that the Carpathian Basin is an ancient habitat of Hungarians who spread around the world from here to conquer and contact other people. This statement of Prime Minister Viktor Orbán presented in Budapest on 24 February 2015, also supports this: "...there is no other country we discuss history so long with, than in the case of our Turkish friends. On such occasions, all legends are mentioned. We both know the idea of being the grandchildren of Attila the great."

It would be impossible to understand the widely popular perception that "Hungarians are used and lonesome people, living in the centre of the Carpathian Basin" without this, as well as the notion of a unique small nation surrounded by Slavs which could only survive due to its knowledge, cultural prevalence ${ }^{8}$ and adroitness. This is supported by politics, as it appears in this speech of Prime Minister Orbán in 2018: "Our common goal is to raise youth who believe in values making it possible for the Magyars to survive for a thousand years, always making do" ${ }^{9}$ A person from the East who loves and protects its freedom, that settled in the heart of Europe and the sense of being "proud Hungarians as Europeans" is shared by almost everyone in the Hungarian community (4). This further supports the rationale and success of campaigns appearing at rallies organised by pro-Fidesz civil society organisations such as the Peace March of 2012 ("We will not become a colony", image 1) or these street posters in 2014 ("Our message to Brussels: respect for Hungarians", image 2).

\section{Image 1}

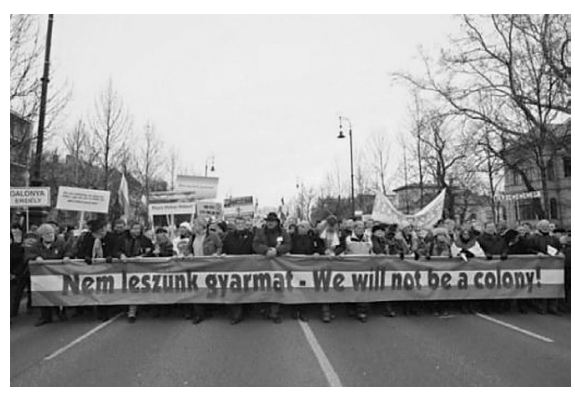

\section{Image 2}

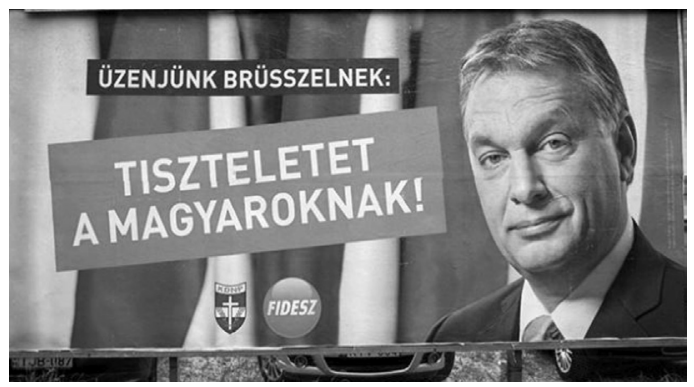

7 http://www.miniszterelnok.hu/beszed/az_a_cel_hogy_erkezzen_gaz_torokorszagbol_magyarorszagra (12 May 2015).

8 This is also prevalent in the works of some great Hungarian thinkers such as István Széchenyi (often dubbed the greatest Hungarian), as well as 19th and early 20th Century cultural ministers Ágoston Trefort and Kunó Klebersberg (respectively).

9 The speech of Viktor Orbán at the inauguration of the National Centre for the Hungarian Boy Scouts Association, 27 May, 2018, Nagykovácsi. Available at: http://www.miniszterelnok.hu/orban-viktor-beszede-a-magyar-cserkeszszovetseg-orszagos-kozpontja-a-teleki-tisza-kastely-avatasan (13 January 2019). 
The Hungarian national spirit would also be incomprehensible, as well as the dispute defining all political discourse for more than a century, which focuses on these people bridging the gap between the East and the West, that is proud of its past, independence and tries to find its true nature at the edge of the two worlds. The shared past and the political-economic efforts are also the explanation for the cabinet's "Opening to the East" policy, announced after 2010 (Tarrósy - Vörös 2014). It is Hungary's response to a trend in the world economy which understands that the future economic potential underlies in emerging Eastern regions and thus these territories are open market opportunities for Hungary. This is supported by a statement of Viktor Orbán: "A person needs to be proud of their national identity to be powerful". "In Europe, Hungarians are the most western oriental people [...] today it is an honour to be called an oriental person."10 Interestingly - partly supporting and partly refuting the above - according to research, being a part of Europe is clearly an evident choice of values for Hungarians. The consequent government propaganda against the EU and Brussels from 2014 (in a more powerful tone than previously) has made many people uncertain, but still, among the four Visegrad countries, Hungary is the most Western-oriented and the popularity of both NATO and the EU is the highest in Hungary. According to a survey carried out by the Political Capital research institute in 2016, in a geopolitical and cultural sense, almost half of all Czech and Slovakian respondents placed their country "midway" between the East and the West. Still, however, Western orientation is strong in both countries. Although general support for NATO membership is quite high in Hungary, Hungarians also tend to be susceptible to the typical conspiracy theories related to the organisation. ${ }^{11}$

Since few written sources of pre-14th century Hungarian history are available, and most of these are vaguely worded and hard to interpret, disputes about the origins of the Magyars frequently arise. After some time, the related discourse was extended to cover scientific theories on the origins of the Hungarian language and its language family, as well as issues related to teaching history. Several subcultures of variable depth and intensity have surfaced related to the examination, research, re-enactment and transfer of knowledge related to the topic, with a clearly strong identity-building role. From the last third of the 19th Century to the Second World War, serious research efforts were conducted in Hungary to study relations to Asian people and to identify ancient Hungarian myths. According to the main programme of the new direction, we, Hungar-

10 Hungary ready to open a new chapter of Hungarian-Turk cooperation, Available at: http://www.kormany. hu/hu/a-miniszterelnok/hirek/magyarorszag-keszen-all-a-magyar-turk-egyuttmukodes-uj-fejezetenek-megnyitasara (3 September 2018).

11 Foreign policy orientation in Hungarian society - Political Capital research (17/11/2016) Available at: http://www.politicalcapital.hu/wp-content/uploads/pc_kulpolitikai_orientacio_20161117.pdf (22 April 2018). 
ians, overestimate the West and since Hungarians are originally people from Asia, in order to become Europeans, we have to look for where we came from. This complex set of ideas blending cultural, religious, anthropological and psychological elements, in addition to scientific research, has given ground to the paradigm of "oriental people finding a new home in the West" (Ablonczy 2016). Although the scientific works of acclaimed historians and archaeological artefacts do not support the theories of alternative Hungarian history (or only in small parts), disputes do not seem to quiet at all. On the contrary, they gain momentum through expectations and beliefs of society, a vast range of uncontrolled, pseudo-scientific sources, online opportunities to gradually make people more confused and also through political considerations. These together have an impact that aligns with the objectives of online fake news forums as well: to make people doubt basic facts, knowledge, norms and meanwhile to destabilise and incite chaos and disorder (5).

The emotions unleashed after the transition to democracy in 1989/1990, as well as the swiftly deteriorating political and economic circumstances, jointly triggered a whole lot of conspiracy theories. Some of these build on the theories of a veiled global power and the financial elites controlling it, which reinforces a sense of vulnerability, creating a sceptical and strongly anti-elitist attitude. This story suggests that the failures of Hungarians and the unfulfilled hopes are exclusively the works of the veiled power (often identified with Jews (the "New York-Tel Aviv-Budapest axis") and the Hungarian politicians who serve its interest. Therefore, Hungarians have to fight a constant 'freedom fight' against these internal and external factors (Krekó 2018). Based on a survey, 40-60\% of Hungarians believe that:

1. Veiled powers use the crisis to colonise and destroy Hungary;

2. Others govern instead of the government, such as 'hidden powers';

3. The world is ruled by a small group of enigmatic people.

After the transition to democracy, more and more people started to question the facts about Hungarian history described in history books and what was being taught in schools. A common element in each alternative approach is that Hungarian history has been falsified consciously and systematically, with covering up existing knowledge and removing or misrepresenting facts (by the Habsburgs, communists, foreign powers intending to colonise Hungary, etc.) (Lendvai 2011). One of the most important questions is the following: why should it be concealed that the period before King Saint Stephen leads up to leader of the Hungarian tribes, Árpád, while he is a descendant of Attila and the Huns? This 'proves' that the theory of Finno-Ugric ${ }^{12}$ linguistic relations is

12 According to the currently generally accepted position of Hungarian and international linguistic science, the Hungarian language is also a member of the Finno-Ugric family of languages, comprising the Ugric 
untrue, even though it is currently the cornerstone of Hungarian scientific history and education. Such alternative theories tend to increase the historic role of Hungarians in human civilisation. In addition to Hun-Hungarian, theories of Sumerian-Hungarian language relationships are also highlighted, as well as the concepts of the Turkic origin of Szeklers (or Székelys, a Hungarian group of people living in Transylvania). The presumable purpose of the conspiracy is to deprive Hungarians of their identity and support maintaining rule over them (Pap-Glied 2018). This is supported by common public perception, professed by many members of the alternative Hungarian history researcher/reader subculture, with a significant number of followers on social media: What do you mean, it is not a foreign power writing (rewriting) Hungarian history? The proponents from the "Hungarian" Academy of "Sciences" are not Hungarian. Similarly to the real controllers of the governments imposed on us for 70 years, who are not Hungarian either. And then, it is obvious that we are oppressed by a foreign power. ${ }^{13}$

\section{The triumph of populism - the migration crisis}

In my opinion, consciously constructed populism appeared in Hungary after 2004 and extended throughout the subsequent economic and moral crisis, while since 2015, this has practically driven every political action. Viktor Orbán and then Ferenc Gyurcsány also introduced several novelties to political language in the 2000s. Their speeches often contained exaggerated, demagogic statements, metaphors and symbolism which were known in public speech so their references and thinly-veiled messages could not be denied. While Gyurcsány was less keen to 'tend to' the spirit of the people, Orbán pays attention to this. He did not want to change the way Hungarians think but aligned his political messages to this was of thinking. With reference to the national consultations (guided surveys) launched after 2010, the government's communication reflects the will of the people in all aspects, practically making it the executor of this will. Viktor Orbán originally used the term "national consultation" in his 2005 state of the country speech, referring to Fidesz intending to win the 2006 parliamentary elections based on dialogue with voters. ${ }^{14}$ The strategy of "one camp under one flag", followed by Viktor Orbán, contributed to establishing and then maintaining a strongly bipolar political system after 2004, which permanently ripped apart the groups of the political system and society, which was to be open and committed to politics (Körösényi - Patkós 2015: 36). From 2004 to 2010, political conflict escalated to become a duel between the two dominant figures:

branch of the family, together with the Mansi (Vogul) and Khanty (Ostyak) languages.

13 Ők is a magyar történelem meghamisítói. [They are also falsifiers of Hungarian history] Available at: http://www.magyartudat.com/a-magyar-tortenelem-meghamisitoi/. (29 March 2015).

14 The institutionalisation of national consultation was announced by Prime Minister Orbán after the 2010 elections. 
socialist Prime Minister Ferenc Gyurcsány and the leader of the opposition, Viktor Orbán. Acclaimed researchers estimate 2006 to be the vantage point for the crisis of liberal democracy (Bozóki 2014; Bíró-Nagy - Győri - Kadlót 2015; Körösényi - Patkós 2015) when the infamous speech of Ferenc Gyurcsány was leaked in which he recognised that the government had continuously lied to people about the state of the country. This lead to a permanent political crisis, further deepened by the drastic global economic recession after 2008. Populist forces in Central and Eastern Europe reacted to the crisis efficiently. In Hungary, "two especially prominent representatives of the anti-liberal populist wave - Jobbik ${ }^{15}$ and Fidesz - increased their influence." (Enyedi 2015: 50). Fidesz-KDNP had already followed a partially populist strategy before taking over the government in 2010, manifested primarily by emphasising the importance of popular referendums, as well as by communication which blamed the international elite and global/international financial circles for the economic crisis. Meanwhile, the newly established right-wing propaganda machine shouted to Hungarian society that the dominance of liberal norms, the constitution founded on rights and the free market, endangers the existing democracy (Enyedi 2015).

After 2010 (when Fidesz won an overwhelming, two-thirds majority in the national assembly), Ferenc Gyurcsány, as the most obnoxious politician in Hungary, gradually lost his significance (Körösényi 2013). After the repeated two-thirds majority of Fidesz in 2014, the left-wing/liberal opposition was practically destroyed but in the autumn of the same year, the government's rhetoric was also losing breath and the political horizon saw the rise of a new radical right-wing innovation lead by an ambitious young politician, Gábor Vona. The election defeat of Jobbik in 2014 made Party Chairman Vona conclude that radical and extremist buzzwords and appearances are hurdles to any further expansion of the party. Since Vona made it clear that Jobbik aims to take over the government, he launched a new communications direction in late 2014 . Radical topics popular with followers of the party - such as anti-Semitism, 'gypsy crimes', anti-EU sentiment, etc. - as well as any related rhetoric, were restricted and moderated. Following several scandals uncovered in late $2014,{ }^{16}$ in little more than a month, the popularity of Fidesz took a $12 \%$ dive, unparalleled in history after the regime change. ${ }^{17}$ Although the opposition could only benefit from the deep-dive of the governing party to a small extent, Fidesz badly needed a topic to bind its messages to. It was the migrant crisis reaching Hun-

15 Jobbik Magyarországért Mozgalom (Jobbik, the Movement for a Better Hungary), the largest opposition party after 2014 until 2019. From 2003 to 2014, a radical, populist/far-right, from 2015 a radical centre-right populist party.

16 American entry ban scandal and protests against internet tax.

17 Medián: 16 százalékot esett Orbán népszerűsége egy hónap alatt. [Orbán's popularity drops by 16 percent in one month] Available at: HVG. http://hvg.hu/itthon/201450_kiabrandulasrol_tanuskodo_partpreferenciak_2014.12.10. (25 June 2015). 
gary with an elementary force in the spring of 2015 that could halt any more loss of popularity and change its course.

Fidesz and the government gradually introduced and mixed the migration/ refugee topics with terrorism, the problems of co-existence and integration in Europe and the NGOs financed by George Soros, a Hungarian-American financier with a Jewish background, as well as the ineptitude of decision-makers in Brussels (influenced by Soros), which could now be linked to euro-sceptic ideas as well (6). The 'big picture' slowly emerged. The political discourse and communication space created in relation to the migrant crisis balanced on the verge of reality and semi-reality when it expressed and conveyed powerful messages, in multiple stages, to both Hungarian citizens and the migrants. Initially, this caused a great divide in public opinion. The main element of the discourse was the need to protect Hungary and its residents from the impacts of the migrant wave, relying upon the people's need for safety and their instinctive fear and it also highlights the importance of preventive action, thus legitimising the measures taken by the acting party. Conscious of all the above, government political communication succeeded in deliberately confusing refugees with immigrants, illegal migration with legal, as well as migrants with terrorism. The anti-migration campaign started immediately after the bloody attack on the editorial office of the Charlie Hebdo magazine in Paris, in January 2015. The first step of communication was raising awareness with three distinctive elements:

1. As regards the increasing volume of migration in March-April 2015, Hungarian citizens needed to be explained to why hundreds of thousands of migrants with a different culture and religion cross Hungary to Western Europe. The main message was "If you come to Hungary, you have to respect...". The billboards and the television commercials launched in the early summer raised awareness in the Hungarian public through messages addressed to migrants that the situation was severe since the public did not have (and could not have had) any personal experience related to the phenomenon.

2. The government launched mail-in and online national consultations about immigration and terrorism. The two terms have thus been linked.

3. The government's communication and politicians of the governing party attacked the cumbersome and slow decision-making of the European Union, the indulgent and liberal migration policy of Brussels, as well as its politically correct communication, in addition to Berlin's Wilkommenskultur approach, relying on unconditional acceptance.

By appropriating the word "protection", the cabinet strengthened the coherence of its own communication since obviously political, legal and policing means were available to control the wave of migrants. The same was not available to opposition parties and, in addition to this, they were hesitant at the beginning 
of the crisis; they did not have adequate information on how to assess the process realistically and since Fidesz was extremely successful in constructing its own communication, the opposition (including Jobbik) could merely follow governmental communication as of summer, 2015, being unable to control it. Fidesz-KDNP gradually took over almost the entire communication space (Glied - Pap 2016).

The terrorist attack in Paris in November 2015, was the basis to further increase the intensity of communication. According to the Hungarian Premier, the link between immigration and terrorism was undisputed because all terrorists are migrants. The question remains, "when did they come to Europe". The West is at war with Islamists in the Middle East, so it is no surprise that the enemies send warriors among the arriving migrants. If we allow millions of people into Europe without identifying them, the danger of terror is going to increase. Therefore, according to him, external borders have to be secured, the Schengen Zone has to be protected instead of being delayed and working out new ideas is necessary. ${ }^{18}$ The Hungarian government closed down the border with Serbia on 14 September, 2015, with a supposedly temporary border fence also providing physical protection to Hungary.

It is also interesting to assess how the migrant issue has become the highest-ranking item on the political agenda because in Central and Eastern Europe, immigration practically causes no everyday problems. Numerous research has confirmed that, until 2015, citizens of Hungary did not consider the process especially dangerous. ${ }^{19}$ There are no major immigrant groups in Hungary, religious citizens typically follow a Christian denomination and cultural identity is based on Judeo-Christian cultural cornerstones; this is why people consider belonging to a Christian Europe so important. After the transition to democracy, numerous studies have examined xenophobia and discrimination in Hungary. TÁRKI has studied xenophobia since 1992, as well as the attitudes of Hungarian society towards foreigners and minorities. In summary, almost half of all Hungarians, and since 2015, two-thirds of them, basically express rejection or at least prejudice towards immigrants from third-world countries. The higher rate of xenophobia compared to other countries in the region is partly caused by problems of co-existence with the Romani minority, as well as a lack of information. Citizens project Western European problems to their own country and the traditional approach that Hungarians - with their unique language,

18 All the terrorists are migrants - http://www.politico.eu/article/viktor-orban-interview-terrorists-migrants-eu-russia-putin-borders-schengen/?utm_source=mandiner \& utm_medium=link \& utm_ campaign=mandiner_201512 (23 March 2016).

19 Poverty, fear of an uncertain future, emigration all ranked higher in the polls than fear of immigration, however, among other Central and Eastern European countries, the degree of xenophobia is extremely high in Hungary. This is also supported by the Eurobarometer surveys - Standard Eurobarometer 82, Autumn, 2014 Available at: http://ec.europa.eu/public_opinion/archives/eb/eb82/eb82_anx_en.pdf (24 October 2017). 
culture and history - are an island in Europe who have to protect their sovereignty also plays an important role (Glied - Pap 2016). According to research conducted in 2015/2016, the rates of xenophobia did not show a significant difference between voters of different parties, i.e., the migrant crisis and the anti-migrant government campaign succeeded in making rejection general (Simonovits - Szalai 2013).

According to the surveys of TÁRKI and Závecz Research, the level of xenophobia has reached unprecedented heights. By October 2016, not the Romani minority but Arabs have become the most rejected ethnic group. 58\% of the respondents considered themselves openly xenophobic, which is clearly a consequence of the anti-migrant political campaign. After the migration crisis, based on the sense of being threatened and the prospective state of emergency, negative messages have surfaced (We don't want illegal immigrants!; The number of molestations against women have risen sharply in Europe since the beginning of the crisis). As a consequence of the crisis, and also based on the criticism expressed against the European Union, the government has started to reinforce existing euro-scepticism and launched a campaign against Brussels (Let's stop Brussels! Sending a message to Brussels, to make them understand!). Still, however, it was necessary to dehumanise and objectify the enemy ('migrants' instead of refugees!), thus, in an effort to build on populist anti-elitism and link the opposites of "Us" and "Them" with xenophobia, the first posters of the so-called Soros Campaign surfaced in 2017, depicting Hungarians as "Us" and Mr. Soros, Brussels, the veiled power, global capital, Angela Merkel and the German Wilkommenskultur, etc. as "Them" (Don't let Soros have the last laugh! - Figure 3; Soros plans to resettle millions from Africa and the Middle East!) (Kákai - Glied, 2017: 26).

\section{Image 3}

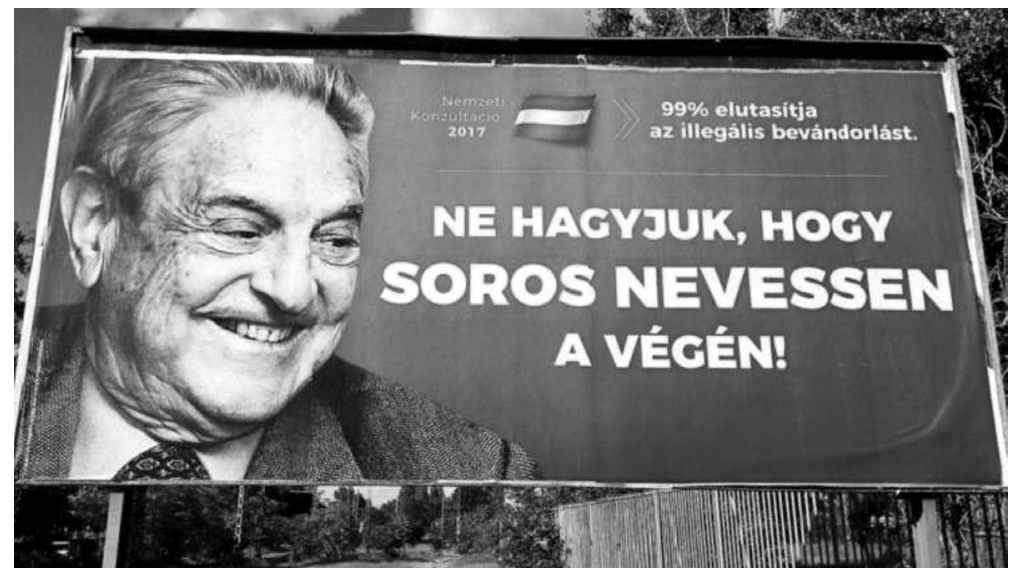


Political bullying and propaganda was manifested in the Stop Soros bill submitted to Parliament in June, 2018, which intended to sanction organisations which promote mass migration and are supported from abroad. ${ }^{20}$ Considering developments observed in political rhetoric, we see the outline of a conscious process of the governing party not only linking populist ideology with xenophobic sentiment but by promoting the two phenomena simultaneously, it also supports its own legitimacy and its influence has become unquestionable in the media and political arena as well (7). From the perspective of the latter, the success of the populist political direction is unquestionable but we still face the dilemma of whether this process can be interpreted within the framework of a democracy and also what damage it does to the mental health of Hungarian society.

\section{Additional remarks}

It is an extremely complex and risky task to discover how a populist-right wing political programme can be this successful since it requires honestly facing our own reflection. We do have exact figures, polls, reports which enable us to understand the opinions, attitudes of voters and any changes thereof. However, we tend to distort responses related to soft factors, national characteristics, psychological approaches or the reasons of human reaction according to our own ideology, desires and ideas. Much of the research conducted in the last decade comprises no more than indefensible explications, as well as already known facts which do not contribute to the discourse with any novelty or fail to face reality under the umbrella of political correctness. Some published materials consciously mask or misinterpret the reasons and many researchers simplify their answers and articulate collective accusations or may even enter the territory of flagellation (of themselves and their people). However, it might be extremely misleading if we only consider a few examples of these explanations individually because they will not bring researchers closer to understanding the phenomenon. We ask questions that are incomprehensible for the majority of the people. Not because they would be unable to comprehend them but because they are not interested in the nature of this system, only the messages. And that is alright. The Curse of Turan, because migrating ancient Hungarians roamed away from their home territory; cultural heritage; characteristic Hungarian self-destruction; the Goulash Communism of the Kádár era and nostalgia; a Mafia State; a Developer State, an octopus of a crime organisation with many tentacles; a hybrid democracy; an operetta democracy; a Putinist democracy; an accumulat-

20 Proposal of the STOP SOROS bill, submitted by the Government of Hungary. Available at: http:// www.kormany.hu/download/c/9a/41000/STOP\%20SOROS\%20 T\%C3\%96RV\%C3\%89NYCSOMAG.pdf. 20/06/2018 (08 January 2019). 
ing state building an authoritarian capitalism? ${ }^{21}$ The list could go on endlessly but we are still no closer to a solution since populist politics takes extremely effective steps, motivated by political advantage. A strong leader, centralisation, state-controlled 'liberal capitalist economy', expanding bureaucracy, personal hierarchical relations, the creation of a national capitalist class, destroying the fundaments of long-term competitiveness and development, all in order to satisfy the short-term demands of 'national' capital, propaganda, symbolic political activities, doublespeak, etc. (Pálné et. al. 2017). Indeed, these all contribute to getting the right picture but only get us closer to a better understanding, not to definitive explanations.

While taking a stance for order and against corruption, promising to make the criminal code stricter or meeting the expectations of the majority, populist politics approve the demands. Keeping the idea of restoring the death penalty on the agenda (Fidesz, Jobbik), forced emotions and crying (Gyurcsány), awkward appearances on talk shows, overacted 'unexpected' events and the almost cynically repeated buzzword of "hard-working ordinary people" (Fidesz) may give way to a sense that some politicians pursue popularity to such an extent that they absolutely believe that people are stupid but if they understand this, then why do it? Possibly because many people believe deception, misleading, lying, reframed reality and propaganda based on a system of half-truths without any reservations. There is a pre-fabricated worldview for them, an alternative which can be accepted without even thinking since no one has time for that nowadays... Politicians also know and understand this and when they smell success, they will use it, which Viktor Orbán did not deny in a speech in 2018: "We act rightfully when we can bend reality according to our own way of thinking, our own personal will. As a politician, I think this is the essence of innovation."22

The fact that fear, danger and uncertainty trigger deep human reactions cannot be denied. As a former staff member explained, Arthur Finkelstein and his team had developed a campaign for Fidesz which was based on currently existing factors - the uncontrolled wave of migrants - as well as on stigmatising György Soros and the organisation he supports, alongside doubting the decisions taken by Brussels (the EU). They selected multiple identified and faceless enemies for the negative campaign who were unable to defend themselves or strike back, who could continuously be attacked and onto whom everything voters consider bad could be projected but they also played on the centuries-long

21 Scheiring, Gábor: Az Orbán-rendszer természete: autoriter kapitalizmus és felhalmozó állam [The nature of the Orbán system: the authoritarian capitalism and the accumulating state] Available at: https:// merce.hu/2018/12/25/az-orban-rendszer-termeszete-autoriter-kapitalizmus-es-felhalmozo-allam (27 December 2018).

22 Orbán: Képesek vagyunk akaratunk szerint hajlítani a valóságot. [We can bend reality according to our own will] Available at: https://index.hu/gazdasag/2018/05/29/orban_egyedulallo_eszjarasa_van_a_ magyaroknak. (20 January 2019). 
anti-power stance of Hungarians, redirected this time at the Belgian capital of liberalism, the seat of the EU. According to this artificial narrative, Hungary is under siege (like so many times throughout its history) and it has to defend itself; against the (mostly Muslim) illegal migrants on the one hand and against international financial capital and the dictatorial efforts of Brussels on the other. Our partners are not helping us (except for the Visegrad countries, especially Slovakia and Poland) in this fight, so we have to go into battle alone to protect our values and Western Christianity. We are already experiencing the degree to which the anti-migrant and anti-Soros campaign succeeded at in increasing the level of xenophobia in Hungary but we as yet only have gloomy ideas about the long-term impacts. Birnbaum gave a very interesting answer to the question asking how responsible he feels for what happened: "Our campaign has not turned anyone into an anti-Semite, if they hadn't been one before. We might only have shown them a new victim; nothing else happened. There is nothing I would do differently." 23 This sentence includes everything that makes populism successful. Populists actually or apparently react to the expectations of the 'people', quasi-fulfilling them, which cannot really be complained about. I see the main issue as a lack of responsible behaviour and liable decision-making because co-existence and considering climate change - survival, would definitely require these. Most of the people who understand history know where a prevalence of unrestricted, extreme populism leads to. Others deliberately, due to their political interests, fail to understand or concede to this. This is a dilemma that poses a serious challenge to mankind from time to time and we probably think that the answer is complex, whereas it is actually very simple: if liberal democratic systems are unable to find a solution to the problems affecting people, if they fail to mitigate crises, then the age of stupidity will exist under the guardianship of populism.

\section{References}

Ablonczy, Balázs (2016): Keletre, magyar! A magyar turanizmus története. Jaffa kiadó, Budapest.

Antal, Attila (2017): A populizmus vizsgálata demokráciaelméleti perspektívákban. Politikatudományi Szemle XXVI, 2017/2: 129-148.

Bayer, József (2008): A populizmus kísértése az új demokráciákban. In: Csefkó Ferenc - Horváth Csaba (szerk.): A demokrácia deficitje avagy a deficites hatalomgyakorlás. Pécsi Tudományegyetem Állam- és Jogtudományi Kara, Pécs-Baranyai Értelmiség Egyesület, Pécs, 2008. 39-52.

Bibó, István (2012): Eltorzult magyar alkat, zsákutcás magyar történelem - Bibó István munkái 7. Argumentum Kiadó.

23 Fidesz campaign advisors spill the beans: this is how Soros became the perfect enemy. Available at: https://24.hu/belfold/2019/01/14/soros-gyorgy-fidesz-kampany-arthur-finkelstein-george-birnbaum/. 14/01/2019 (11 March 2019). 
Bíró-Nagy, András - Győri, Gábor - Kadlót, Tibor (2015): A populizmus az új korszellem? A populista pártok helyzete Európában 2015-ben. Friedrich-Ebert-Stiftung, Budapest.

Bretter, Zoltán (2016): The name of the game: The Regime of National Collaboration. Hungary and Poland in Times of Political Transition. Selected Issues. edited by Beata Pająk-Patkowska and Marcin Rachwat, Poznań: Faculty of Political Science and Journalism - Adam Mickiewicz University, 39-57.

Canovan, Margaret (1999): Trust the People! Populism and the Two Faces of Democracy. Political Studies 47 (1): 1-16.

Csepeli, György - Örkény, Antal (1996): A magyar nacionalizmus változó arca. [The changing face of Hungarian nationalism] In. Andorka. Rudolf; Kolosi, Tamás; Vukovich György (ed.): Társadalmi Riport. TÁRKI, Budapest

Deák, Máté (2019): Chile és Bolívia államközi konfliktusainak áttekintése a XIX-XXI. században. In. Pap, Norbert - Domingo, Lilón - Szántó, Ákos (eds.): A tér hatalma - a hatalom terei: Tanulmánykötet a 70 éves Szilágyi István professzor tiszteletére. Pécs, Magyarország: Pécsi Tudományegyetem Természettudományi Kar. 51-59.

Enyedi, Zsolt (2015): Paternalista populizmus a Jobbik és a Fidesz ideológiájában. Fundamentum XIX, 2015/2-3: 50-61.

Glied, Viktor - Pap, Norbert (2016): The 'Christian Fortress of Hungary' - The Anatomy of the Migration Crisis in Hungary. In. Yearbook of Polish European Studies. Vol 19/2016. Centre for Europe, University of Warsaw.

Győri, Gábor (2008): Populizmus és kormányzás. DEMOS Magyarországi Alapítvány, Budapest. Gyurácz, Ferenc (2017): Populizmus - Tanulmányok, 1991-2017. Magyar Nyugat Könyvkiadó.

Hamerli, Petra (2020): Common Points in the Policy of Italy and Central Europe. Politics in Central Europe 16(18): In this volume.

Harari, Yuval Noah (2018): 21 lecke a 21. századra. Animus Kiadó, Budapest.

Kákai, László - Glied, Viktor (2017): Sketch of the Hungarian non-profit sector after the regime change. Civil Szemle, 14/3: 13-34.

Kocijan, Bojana (2015): Who is populist in Central and Eastern Europe? A comparative analysis of prime ministers' populist discourse. Corvinus Journal of Sociology and Social Policy 6 (1): 71-92. DOI:14267/cjssp.2015.01.04.

Kovács, Gábor (2011): A politikai eszmetörténet próteusza: a populizmus. In. Pénzes, Ferenc Rácz, Sándor - Tóth-Matolcsi, László: A szabadság felelőssége. Írások a 65 éves Dénes Iván Zoltán tiszteletére. Debreceni Egyetemi Kiadó, Debrecen, 2011. 259-275.

Körösényi, András - Patkós, Veronika (2015): Liberális és illiberális populizmus - Berlusconi és Orbán politikai vezetése. Politikatudományi Szemle XXIV/2: 29-54.

Körösényi, András (2013): Political Polarization and its Consequences on Democratic Accountability. Corvinus Journal of Sociology and Social Policy 4(2): 111-138.

Krekó, Péter (2018): Tömegparanoia. Az összeesküvés-elméletek és álhírek szociálpszichológiája. Athenaeum Kiadó, Budapest.

Laclau, Ernesto (2011): A populista ész. Noran Libro Kiadó, Budapest. 
Le Bon, Gustave (2002): The Crowd: A Study of the Popular Mind. Dover Publications.

Lendvai, Paul (2011): Az eltékozolt ország. Noran Libro Kiadó, Budapest.

Mair, Peter (2002): Populist Democracy vs. Party Democracy. In: Yves Mény - Yves Surel (eds.):

Democracies and the Populist Challange. Palgrave, 81-97.

Müller, Jan-Werner (2018): Mi a populizmus. Libri Kiadó, Budapest.

Nyíri, Pál (2003): Idegengyűlölet Magyarországon - regionális összehasonlítás. 2000, Volume XV, 2003/11. 15-25.

Pap, Norbert - Glied, Viktor (2018): Hungary's Turn to the East: Jobbik and Islam. Europe-Asia Studies 70(7): 1036-1054.

Pálné, Kovács Ilona - Bodor, Ákos - Finta, István - Grünhut, Zoltán - Kacziba, Péter - Zongor, Gábor (2017): Farewell to decentralisation: The Hungarian story and its general implications. Croatian and Comparative Public Administration 16 (4): 789-816.

Schmidt, Andrea (2018): Challenges of the Illiberal Democracy in Hungary. Some Aspects to the 2018 Elections. Polish Political Science Review / Polski Przeglad Politologiczny 2353-3773, 6 (2): 70-90.

Simonovits, Bori - Szalai, Boglárka (2013): Idegenellenesség és diszkrimináció a mai Magyarországon. Magyar Tudomány 3: 251-262.

Skolkay, Andrej (2000): Populism in Central Eastern Europe. In. Thinking Fundamentals, IWM Junior Visiting Fellows Conferences, Vol. 9: Vienna.

Tarrósy, István - Vörös, Zoltán (2014): Hungary's Global Opening to an Interpolar World. Politeja (28): 139-162.

Taguieff, Pierre-André (1995): Political Science Confronts Populism: From a Conceptual Mirage to a Real Problem. Telos, 1995/Spring. 9-43.

Van Reybrouck, David (2010): A populizmus védelmében. Gondolat Kiadó, Budapest.

Vörös, Zoltán (2016): Directions for development of political systems - decrease in legitimacy. In. Beata, Pająk-Patkowska - Marcin, Rachwat (eds): Hungary and Poland in Times of Political Transition. Selected Issues. Poznan, Adam Mickiewicz University Press. 25-38.

Viktor Glied, PhD in political science, assistant professor at the University of Pécs, Hungary. He is historian and political scientist. His research interests cover ecopolicy, civil society, Hungarian and international history in the 20th-21st centuries and migration issues. He is the author and editor of several academic books and studies, furthermore member and contributor of researches that examine different aspects of political science, migration and sustainable development. 